\title{
Simulasi Pengaruh Jumlah Lubang pada Ring Fiksasi Eksternal untuk Tulang Tibia
}

\author{
(Simulation of The Effect of External Fixation Ring Holes Number for Tibia)
}

\author{
KRISDIYANTO
}

\begin{abstract}
External fixation is a device that is placed out of soft tissue. External fixation device is used to heal open fracture. Open fracture is fracture that soft tissue is broken. That device consist of pin, rod, and clamp. We should pay attention of external fixation stiffness. Number of rod can be increased to get this device more stabil. That device should be stabil so fracture position and pin track doesn't move. External fixation that consist three rod usually use rin. This research aims to get the effect of external fixation ring holes number to stiffness.
\end{abstract}

Keywords: fiksasi eksternal, finite element, kekakuan, ring

\section{PENDAHULUAN}

Fiksasi eksternal merupakan perangkat yang dipasang di luar soft tissue dengan tujuan menstabilkan posisi fracture pada tulang. Perangkat tersebut terdiri dari komponen pin, clamp, dan rod (Rüedi, 2000). Fiksasi eksternal dipakai pada penyembuhan fracture dengan soft tissue rusak atau bisa disebut open fracture. Pemakaian fiksasi eksternal pada proses penyembuhan open fracture mempunyai keuntungan supplai darah tidak terlalu terganggu sehingga proses penyembuhan relatif lebih cepat (Rüedi, 2000). Fiksasi eksternal harus stabil supaya pin tidak bergeser. Kestabilan fiksasi ekstenal dapat dinaikan dengan cara menambah jumlah rod (Weber, 1985). Fiksasi eksternal yang terdiri dari tiga rod biasanya menggunakan ring sebagai penghubung (Solonin, 2008). Open fracture pada tulang tibia merupakan kasus paling banyak terjadi akibat kecelakaan lalu lintas. Kasus tersebut juga paling banyak dibandingkan kasus fracture pada tulang panjang yang lain $(\mathrm{Xu}, 2014)$.

Penelitian ini mempunyai tujuan untuk mendapatkan hasil pengaruh jumlah lubang dan jarak lubang pada geometry ring fiksasi eksternal terhadap nilai kestabilan komponen tersebut. Skema simulasi pengujian yang dilakukan pada penelitian ini menggunakan standar ASTM F 1541-02 yang berjudul Standar Specifications and Test Methods External fixation.

\section{Metode Penelitian}

Penelitian ini terdiri dari beberapa langkah. Langkah pertama yang dilakukan yaitu membuat geometry ring fiksasi eksternal untuk tulang tibia. Geometry tersebut dianalisis menggunakan perangkat lunak Autodesk Inventor 2019 dan Nastran in Cad 2019. Langkah-langkah penelitian ini secara detail tersaji pada Gambar 1. Hasil analisis berupa distribusi tegangan dan displacement yang terjadi ketika nilai tegangan maksimum yang terjadi luluh. Nilai gaya yang dipakai ketika nilai tegangan maksimum mengalami luluh dibagi displacement yang terjadi merupakan nilai kekakuan komponen tersebut (Pervan, 2016) Rumus untuk menghitung nilai kekakuan tersaji pada persamaan (1). Hasil perhitungan yang dilakukan disajikan pada grafik. Variasi penelitian ini tersaji Tabel 1 .

$$
C p=\frac{F}{\delta} \quad(\mathrm{N} / \mathrm{mm})
$$

Salah satu geometry pada penelitian ini tersaji pada Gambar 2 sedangkan hasil mesh tersaji pada Gambar 3 dan Gambar 4. Variasi penelitian ini tersaji Tabel 1. 


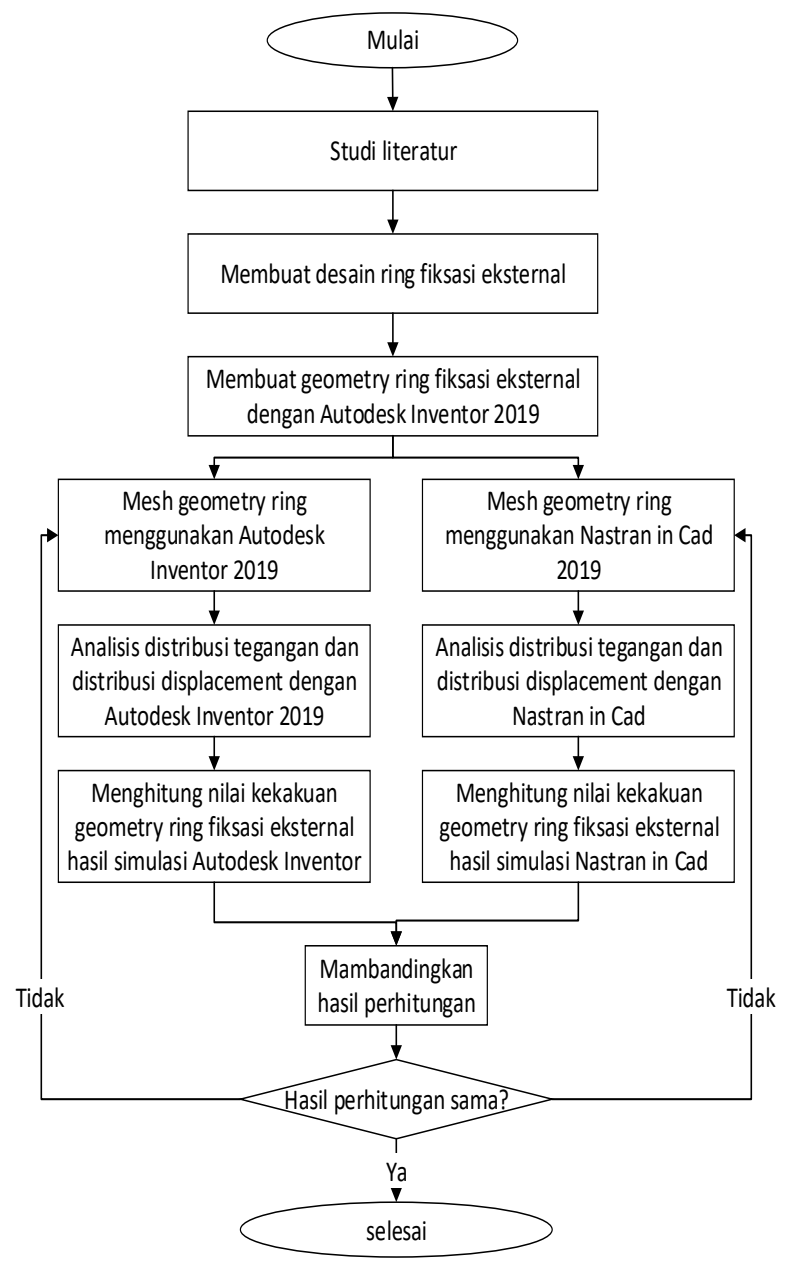

GAMBAR 1. Langkah-langkah penelitian

TABEL 1. Variasi penelitian

\begin{tabular}{ccc}
\hline No & Jumlah lubang & Jarak lubang $\left(^{\circ}\right)$ \\
\hline 1 & 2 & 180 \\
\hline 2 & 4 & 90 \\
\hline 3 & 6 & 60 \\
\hline 4 & 8 & 45 \\
\hline 5 & 10 & 36 \\
\hline
\end{tabular}

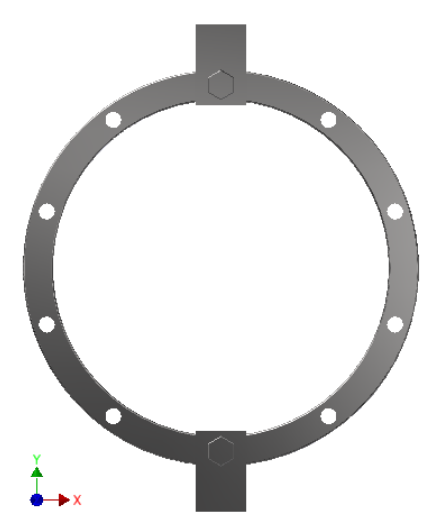

GAMBAR 2. Geometry ring dengan jumlah lubang 10

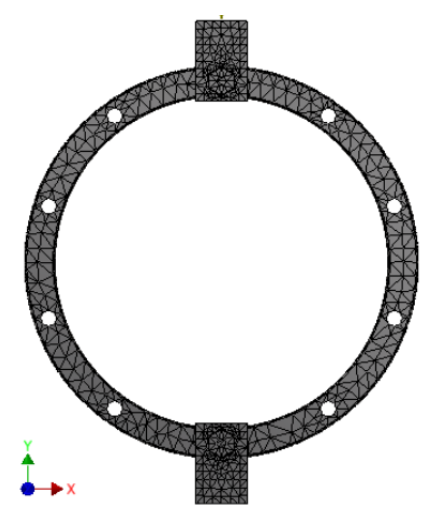

GAMBAR 3. Hasil mesh geometry menggunakan Autodesk Inventor 2019 


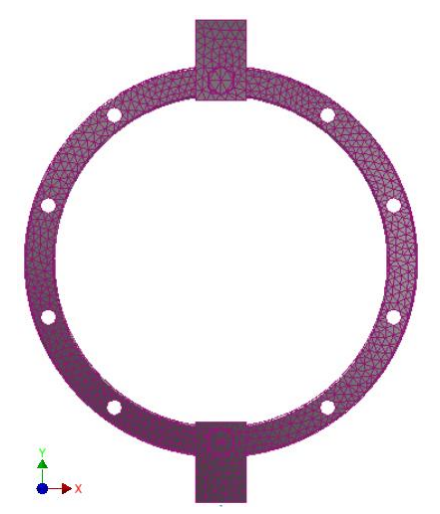

GAMBAR 4. Hasil mesh geometry menggunakan Nastran in Cad 2019

\section{HASIL DAN PEMBAHASAN}

Hasil simulasi menggunakan perangkat lunak Autodesk Inventor 2019 dan Nastran in Cad
2019 berupa distribusi tegangan yang terjadi pada geometry struktur ketika mengalami luluh tersaji pada Tabel 2, sedangkan distribusi displacement tersaji pada Tabel 3 .

TABEL 2. Hasil simulasi distribusi tegangan

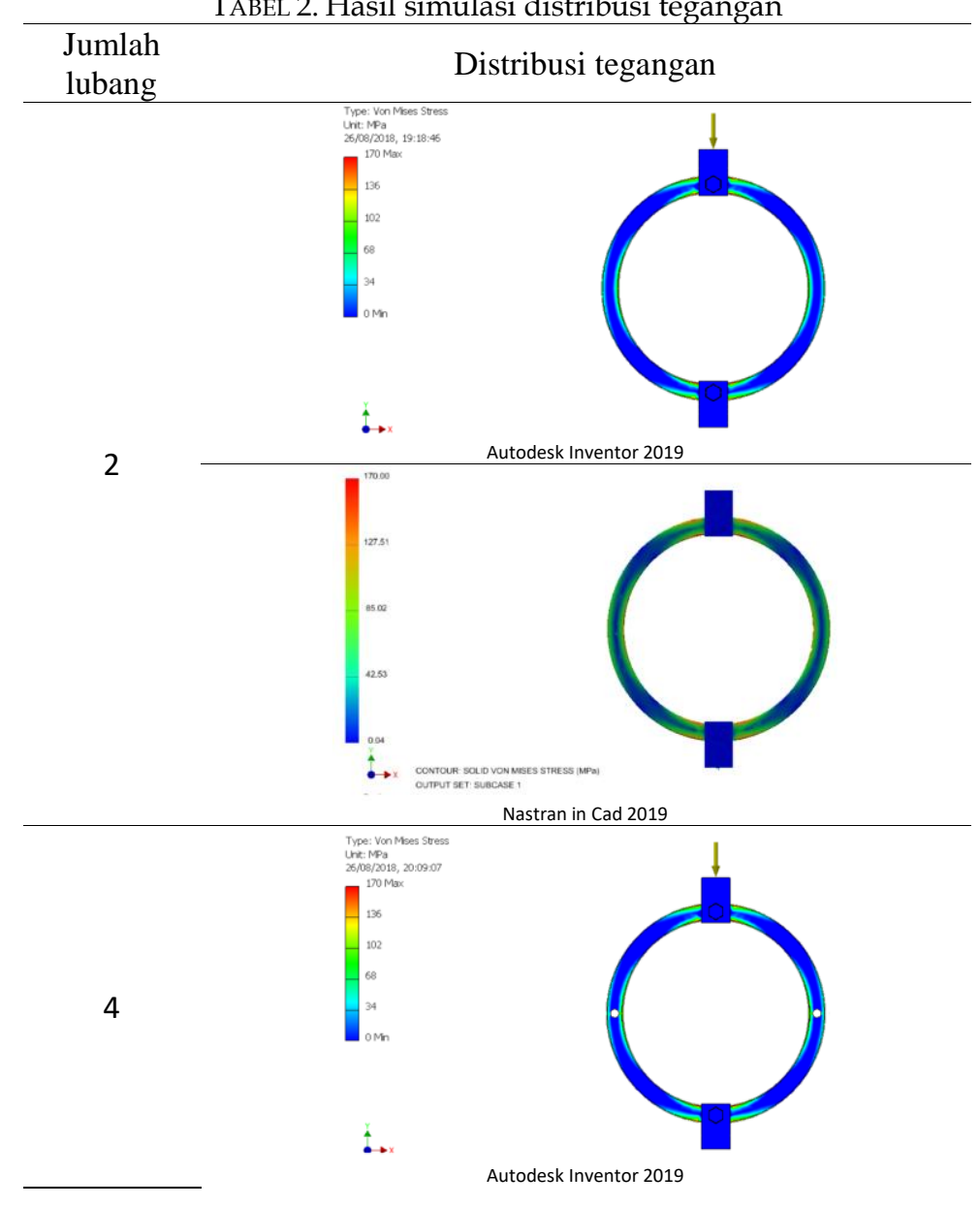




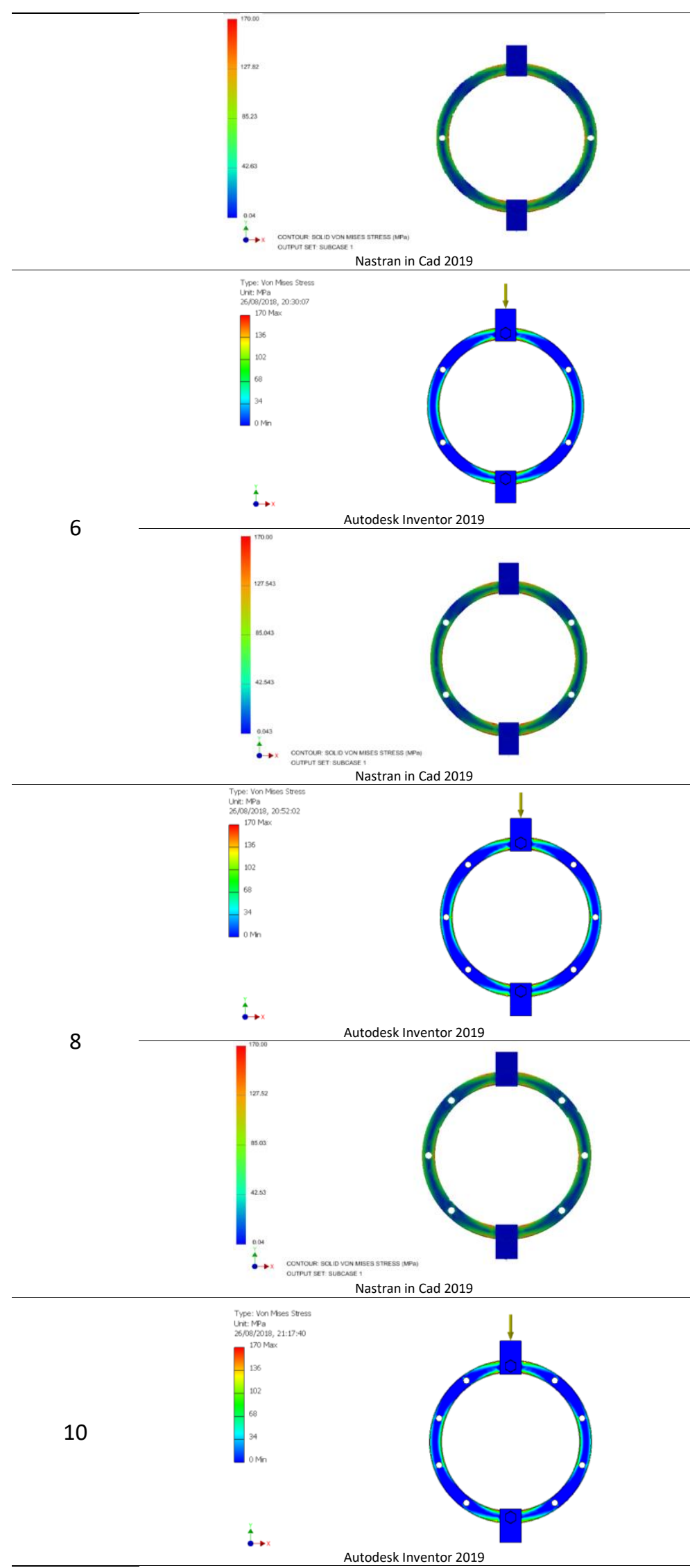




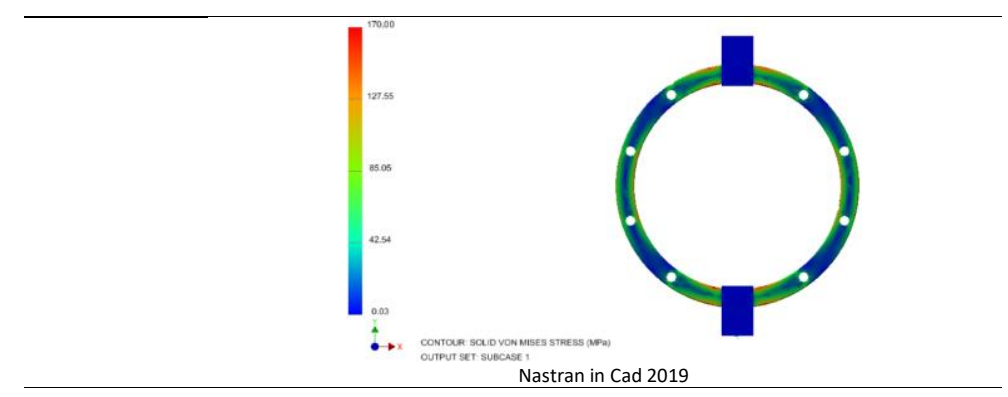

TABEL 3. Hasil simulasi distribusi displacement

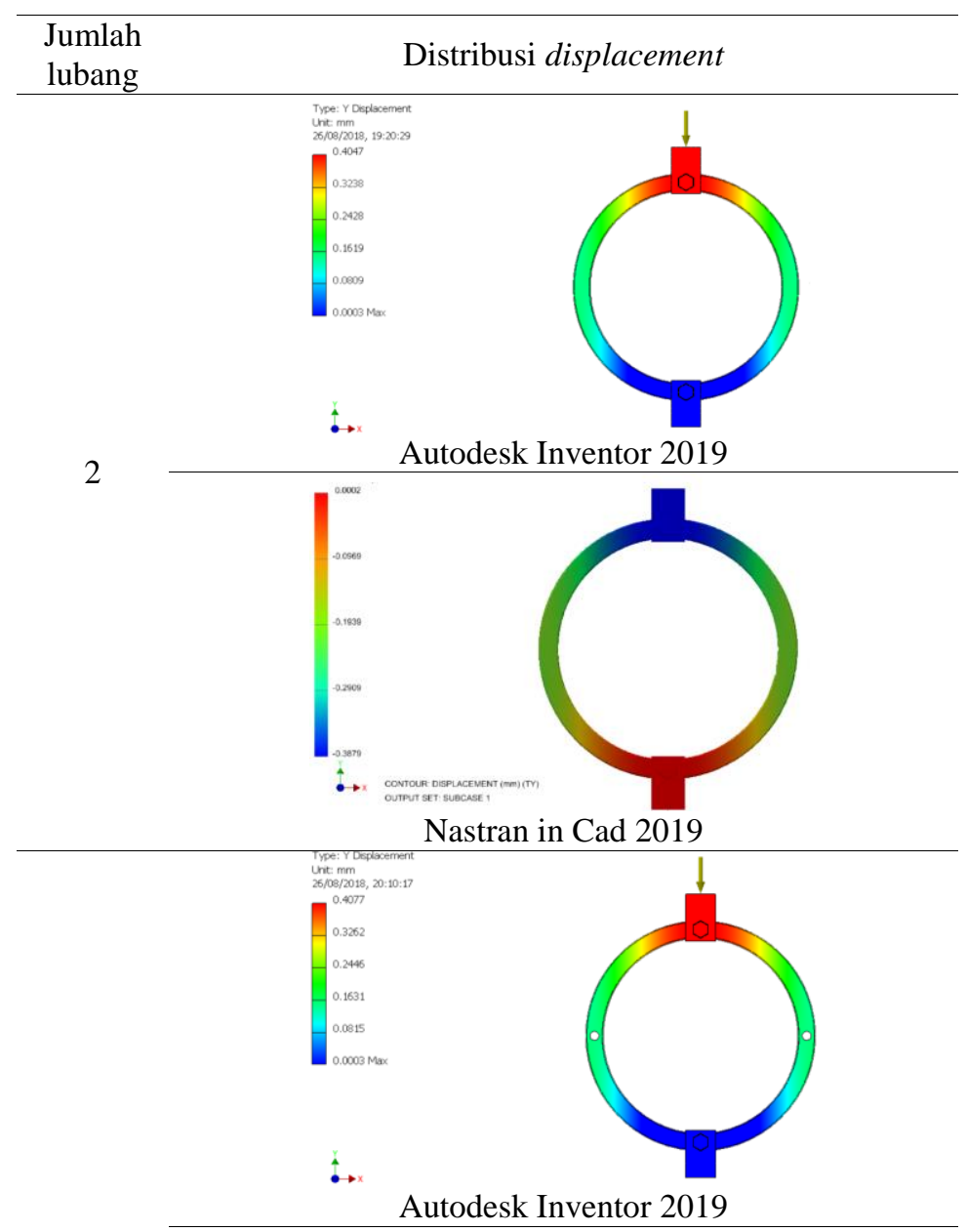

4

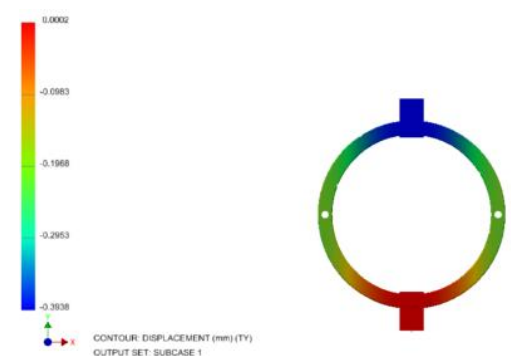

Nastran in Cad 2019 


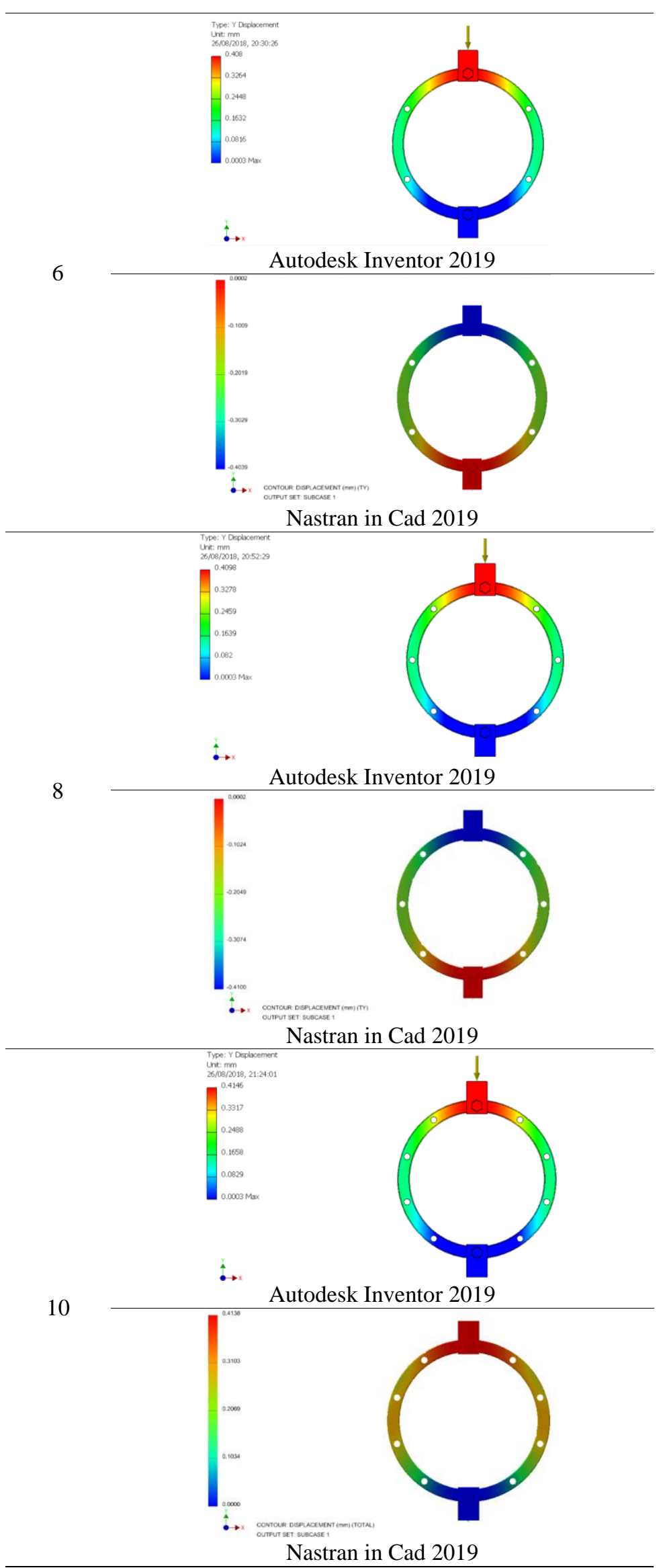


TABEL 4. Gaya yang digunakan dan displacement maksimum ketika geometry mengalami luluh menggunakan Autodesk Inventor 2019

\begin{tabular}{ccccc}
\hline No & $\begin{array}{c}\text { Jumlah } \\
\text { lubang }\end{array}$ & Gaya (N) & Displacement $(\mathrm{mm})$ & $\begin{array}{c}\text { Kekakuan } \\
(\mathrm{N} / \mathrm{mm})\end{array}$ \\
\hline 1 & 2 & 475,39 & 0,4047 & 1174,67 \\
\hline 2 & 4 & 475,80 & 0,4077 & 1167,03 \\
\hline 3 & 6 & 474,60 & 0,4080 & 1163,22 \\
\hline 4 & 8 & 473,01 & 0,4098 & 1154,25 \\
\hline 5 & 10 & 474,20 & 0,4146 & 1143,75 \\
\hline
\end{tabular}

TABEL 5. Gaya yang digunakan dan displacement maksimum ketika geometry mengalami luluh menggunakan Nastran in Cad 2019

\begin{tabular}{ccccc}
\hline No & $\begin{array}{c}\text { Jumlah } \\
\text { lubang }\end{array}$ & Gaya $(\mathrm{N})$ & Displacement $(\mathrm{mm})$ & $\begin{array}{c}\text { Kekakuan } \\
(\mathrm{N} / \mathrm{mm})\end{array}$ \\
\hline 1 & 2 & 455,10 & 0,3879 & 1173,25 \\
\hline 2 & 4 & 455,67 & 0,3939 & 1156,82 \\
\hline 3 & 6 & 467,93 & 0,4039 & 1158,54 \\
\hline 4 & 8 & 449,85 & 0,4100 & 1097,20 \\
\hline 5 & 10 & 465,63 & 0,4138 & 1125,24 \\
\hline
\end{tabular}

Displacement yang terjadi dan gaya yang digunakan ketika geometry struktur mencapai luluh pada simulasi menggunakan perangkat lunak Autodesk Inventor 2019 tersaji pada Tabel 4, sedangkan ketika menggunakan Nastran in Cad tersaji pada Tabel 5.

Hasil simulasi pengujian yang disajikan pada Tabel 4 dan Tabel 5 dibuat grafik pengaruh jumlah lubang dengan kekakuan geometry ring fiksasi ekstenal. Grafik hubungan jumlah lubang dengan kekakuan pada geometry ring fiksasi eksternal tersaji pada Gambar 5.

Hasil simulasi pengujian menggunakan perangkat lunak Autodesk Inventor 2019 menunjukan nilai kekakuan paling besar terjadi pada geometry ring dengan lubang berjumlah 2 sebebsar 1174,67 N. Nilai kekakuan geometry ring paling kecil terjadi pada geometry ring dengan jumlah lubang 10 sebesar 1143,75 $\mathrm{n} / \mathrm{mm}$. Geometry ring yang mempunyai lubang berjumlah 10 nilai gaya yang digunakan sebesar $475,80 \mathrm{~N}$ dan menghasilkan displacement sebesar 0,4077 $\mathrm{mm}$. Gaya tersebut merupakan gaya paling besar yang digunakan dibandingkan variasi geometry ring yang lain. Gaya yang paling kecil digunakan pada penelitian ini sebesar 473,01 $\mathrm{N}$ dan menghasilkan displacement $0,4098 \mathrm{~mm}$. Gaya tersebut digunakan pada geometry ring dengan jumlah lubang 8. Grafik yang tersaji pada Gambar 5 menunjukan bahwa jumlah lubang semakin banyak maka nilai kekakuan semakin turun.

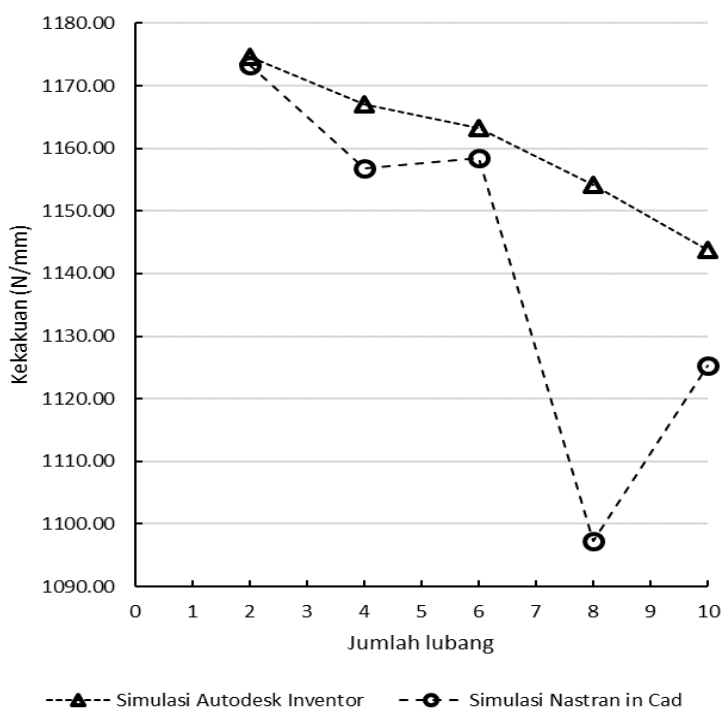

GAMBAR 5. Grafik hubungan jumlah lubang dengan kekakuan 


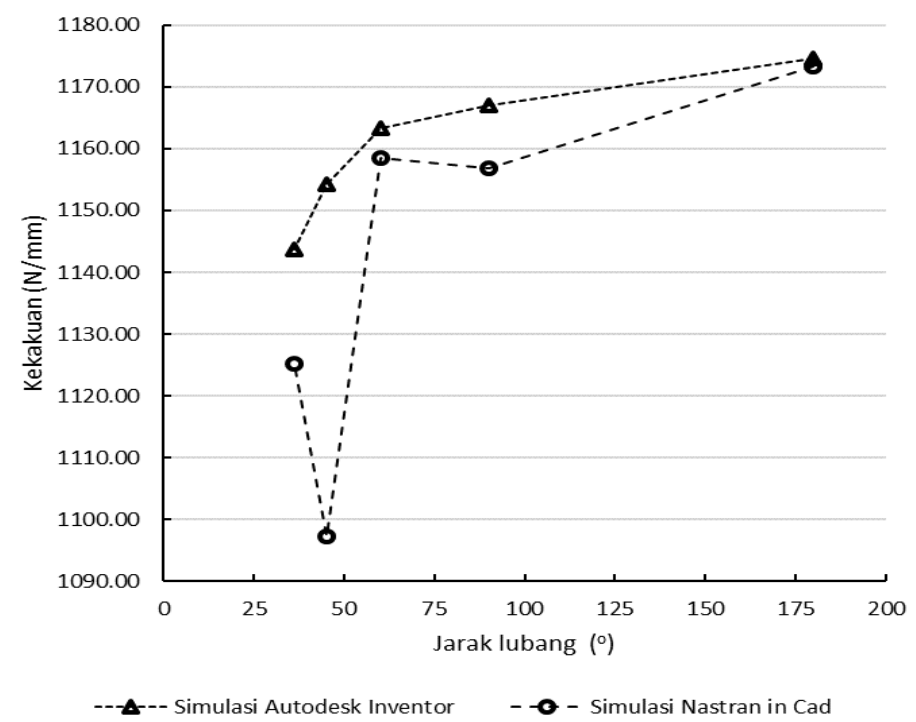

GAMBAR 6. Grafik hubungan jarak lubang dengan kekakuan

Hasil simulasi pengujian menggunakan perangkat lunak Nastran in Cad 2019 menunjukan nilai kekakuan paling besar terjadi pada geometry ring dengan lubang berjumlah 2 sebebsar 1173,25 N. Nilai kekakuan geometry ring paling kecil terjadi pada geometry ring dengan jumlah lubang 8 sebesar 1097,20 n/mm. Geometry ring yang mempunyai lubang berjumlah 6 nilai gaya yang digunakan sebesar 467,93 $\mathrm{N}$ dan menghasilkan displacement sebesar 0,4039 $\mathrm{mm}$. Gaya tersebut merupakan gaya paling besar yang digunakan dibandingkan variasi geometry ring yang lain. Gaya yang paling kecil digunakan pada penelitian ini sebesar 449,85 $\mathrm{N}$ dan menghasilkan displacement $0,4100 \mathrm{~mm}$. Gaya tersebut digunakan pada geometry ring dengan jumlah lubang 8. Grafik yang tersaji pada Gambar 6 menunjukan bahwa nilai kekakuan pada geometry ring dengan lubang 2 lebih besar dibandingkan jumlah lubang 4. Nilai kekakuan pada geometry ring dengan lubang 6 lebih besar dibandingkan ring dengan jumlah ring 4 tetapi masih lebih kecil dibandingkan geometry ring dengan jumlah lubang 2. Nilai kekakuan geometry ring dengan jumlah lubang 8 mempunyai nilai paling kecil dibandingkan nilai kekakuan geometry ring dengan jumlah lubang 2, 4, 6, dan 10. Nilai kekakuan geometry ring yang mempunyai lubang 10 nilainya berada diantara geometry ring dengan jumlah lubang 6 dan 8. Secara keseluruhan rata-rata nilai kekakuan semakin kecil ketika jumlah lubang pada geometry ring semakin banyak.

Hasil simulasi pengujian yang disajikan pada Tabel 1, Tabel 4, dan Tabel 5 dibuat grafik pengaruh jarak lubang dengan kekakuan geometry ring fiksasi ekstenal. Grafik hubungan jumlah lubang dengan kekakuan pada geometry ring fiksasi eksternal tersaji pada Gambar 6.

Hasil pengujian menggunakan perangkat lunak Autodesk Inventor 2019 menunjukan bahwa nilai kekakuan akan meningkat jika jarak lubang semakin besar. Nilai kekakuan paling besar terdapat pada geometry ring dengan jarak lubang $180^{\circ}$ sedangkan nilai kekakuan paling rendah terdapat pada geometry ring dengan jarak lubang $36^{\circ}$. Kesimpulan hasil pengujian menggunakan perangkat lunak Autodesk Inventor 2019 yaitu semakin besar jarak antar lubang geometry ring maka nilai kekakuan semakin besar.

Hasil pengujian menggunakan perangkat lunak Nastran in Cad 2019 menunjukan bahwa nilai kekakuan geometry ring dari variasi geometry ring dengan jarak $36^{\circ}$ sampai $180^{\circ}$ mengalami kenaikan walaupun nilai kekakuan geometry ring dengan jarak lubang $45^{\circ}$ lebih kecil dibandingkan jarak lubang $36^{\circ}$ dan kekakuan pada jarak lubang $60^{\circ}$ lebih kecil dibandingkan $90^{\circ}$ dengan perbedaan nilai relatif kecil.

Nilai rata-rata kekakuan dibandingkan dengan jumlah lubang dan jarak luang pada geometry ring yang tersaji pada Gambar 5 dan Gambar 6 menunjukan bahwa grafik yang dihasilkan dari simulasi pengujian menggunakan perangkat lunak Autodesk Inventor 2019 dan Nastran in Cad 2019 mempunyai trend yang sama. 


\section{KESIMPULAN}

Kesimpulan penelitian ini yaitu:

1) Hasil simulasi pengujian menggunakan perangkat lunak Autodesk Inventor 2019 dan Nastran in Cad menunjukan semakin banyak lubang pada geometry ring fiksasi eksternal nilai kekakuan semakin rendah.

2) Hasil simulasi pengujian menggunakan perangkat lunak Autodesk Inventor 2019 dan Nastran in Cad menunjukan semakin besar jarak lubang pada geometry ring fiksasi eksternal nilai kekakuan semakin tinggi.

\section{UCAPAN TERIMA KASIH}

Terima kasih saya ucapkan kepada Universitas Muhammadiyah Yogyakarta yang selalu memberikan kesempatan kepada saya untuk berkarya.

\section{DAFTAR PUSTAKA}

ASTM Comitee F04 on Medical and Surgical Materials and Devices. Designation F
1541-02. (2002). Standard Specifications and Test Methods for External Skeletal Fixation Devices.

Rüedi, T.P., Murphy, W.M. (2000). AO Principles of Fracture Management. New York. AO Publising.

Solonin, L.N. (2008) The Basic Principles of External Fixation Using the Ilizarov Device. Milan. Springer.

Weber, B.G., Magerl, F. (1985) The External Fixator. Berlin. Springer-Verlag.

Xu, X., Li, X., Liu, L., Wu, W. (2014) A metaanalysis of external fixator versus intramedullary nails for open tibial fracture fixation, Journal of Orthopaedic Surgery and Reseach, (9), 1-7.

PenUlis:

Krisdiyanto

Jurusan Teknik Mesin, Fakultas Teknik, Universitas Muhammadiyah Yogyakarta, Yogyakarta.

Email: krisdiyanto@umy.ac.id 